\title{
The use of greenroofs for the mitigation of environmental problems in urban areas
}

\author{
A. Teemusk \& Ü. Mander \\ Institute of Geography, University of Tartu, Estonia
}

\begin{abstract}
Greenroofs are new technology that can be applied in areas such as present-day cities, where less and less green space is available. Greenroofs have many benefits: they make buildings more thermally efficient, prolong the life of a roof, ameliorate extremes of temperature and humidity, reduce surface water runoff, help to reduce the urban heat island effect, air pollution and noise, and provide green space for people and wildlife. Greenroofs have been studied in many countries, from the point of view of thermal performance, protection of the roof membrane, stormwater retention and runoff quality. Although the results are sitespecific, it is necessary to review these studies. Greenroofs were found to be effective in helping to keep buildings cool in summer and also to reduce building energy consumption. Research showed that planted roofs reduce the temperature fluctuation in the roof membrane. Greenroofs delay rainfall runoff and reduce runoff rate and volume. The results of greenroof runoff water quality showed that they behave as a sink or as source of contaminants in runoff water. The results of the investigation of Light Weight Aggregates (LWA)-based greenroofs in Estonia showed that an extensive greenroof is sufficiently capable of protecting the layers of the base roof from extreme temperatures. Typically, light rain is retained, whereas heavy rain penetrates the greenroof media. The quality of the runoff water varies depending on runoff character and the pollutants accumulated on the roof.
\end{abstract}

Keywords: energy saving, evapotranspiration, greenroof, rooftop garden, runoff quality, thermal performance, water retention.

\section{Introduction}

The main objective of this study is to give a sufficient review of the results of research that has been performed to find out how greenroofs work in reality. We also present the results of the first research into greenroofs in Estonia. 


\subsection{Greenroof term and types}

Greenroofs or rooftop gardens are a specialized roofing system that supports vegetation growth on rooftops. 'Greenroof' is the most common term, but other terms such as 'planted roof', 'vegetated roof', 'grassed roof' or 'eco-roof' are also used. Greenroofs are not a new concept. They have a long history, but today it is rapidly advancing technology that has the potential to improve the quality of urban life. Greenroofs are usually divided into two general categories: extensive and intensive, although mixed types and natural sod roofs [1] are also possible.

'Extensive greenroofs' have a thin substrate layer, low weight, low capital cost and can be installed over the flat roofs of existing buildings. This roof type is not usually designed to be accessible, except for maintenance. Vegetation normally consists of sedums, mosses, succulents, herbs or grasses and is selfsustaining. The thickness of an extensive greenroof's substrate is $<50-200 \mathrm{~mm}$, and its weight can be $<50-220 \mathrm{~kg} / \mathrm{m}^{2}$.

'Intensive roof gardens' have a deep soil layer and because of their great weight, need a stronger building structure. They are usually accessible, and may include lawns, shrubs and tree plantings. The roof garden needs regular maintenance including irrigation, fertilizing and weeding, and is very expensive to build and maintain. The thickness of an intensive roof garden's soil layer is $>200 \mathrm{~mm}$, and its weight can be $200-1000 \mathrm{~kg} / \mathrm{m}^{2}$.

\subsection{Greenroof construction}

Greenroof systems are established mainly on top of an existing roof structure, and consist of certain specific layers $[1,2]$ :

- waterproofing membrane, typically made of polyvinyl chloride (PVC), high-density polypropylene or bituminous fabrics. If waterproof materials are not root resistant, they must be protected from root penetration;

- a drainage layer is needed to remove excess water from the growing medium and also to retain some water for irrigating the plants; a purpose-made fibrous plastic mat or a layer of gravel is often used for this;

- a filter membrane prevents fine particles in the substrate layer from clogging the drainage layer, which is usually a geo-textile filter fabric;

- a substrate layer (growing medium) is selected on the basis of water retention, water permeability, suitability for root growth and plant anchoring properties; the substrate layer usually consists of a mixture of soil, sand, gravel, organic matter and crushed brick; in Estonia a Light Weight Aggregate (LWA), which is lightweight, well-drained and silt-free, is mostly used in the substrate layer; if the roof's slope is more than 20 degrees, supporting baffles are needed;

- plants must be resistant to extreme temperatures, solar exposure, scarce water, as well as an excess of water and stronger winds; plants for extensive greenroofs must be low-growing and shallow-rooted.

\section{Materials and methods}

In addition to a review of studies that have been performed throughout the world, this paper also briefly describes how an LWA-based greenroof works in the 
Estonian climate, as the result of observing an existing greenroof in Tartu. The task was to assess the thermal performance, stormwater retention potential and runoff water quality of a greenroof, and to compare those with modified bituminous membrane roofs (roofs had the same area $-120 \mathrm{~m}^{2}$ ). The studied greenroof consists of the following layers: modified bituminous base roof, plastic wave drainage layer $(8 \mathrm{~mm})$, rock wool for rainwater retention $(80 \mathrm{~mm})$ and substrate layer $(100 \mathrm{~mm})$ with LWA $(66 \%)$, humus $(30 \%)$ and clay $(4 \%)$. The most common plant species are Sedum acre, Thymus serpyllum, Dianthus carthusianorum and Cerastium tomentosium.

The temperature was measured using sensors (Pt1000TG8/E) after every 15 minutes, and recorded with a data logger produced by Comet System. The measuring time was June 2004 to April 2005. As the bituminous membrane of the base roof was inaccessible, the temperature was measured on the surface of both the roof and above the roof at $1 \mathrm{~m}$, and also at the depth of 50 and $100 \mathrm{~mm}$ in the substrate layer. Because the surface of the greenroof was mainly covered by LWA (plant cover was 45\%), the surface temperature expresses the temperature of the LWA. It must also be noted that plant cover was thicker on one side of the roof than the other side, which influenced rainwater runoff results. Stormwater runoff was manually measured on an hourly basis with 20litres canisters, or more frequently when necessary. The greenroof had two outflows, and there was one outflow for the reference roof. Runoff water samples were analyzed for $\mathrm{pH}, \mathrm{BOD}_{7}, \mathrm{COD}$, totalN, $\mathrm{NO}_{3}{ }^{-}, \mathrm{NH}_{4}^{+}$, totalP, $\mathrm{PO}_{4}{ }^{3-}, \mathrm{SO}_{4}{ }^{2-}$, $\mathrm{Ca}^{2+}$ and $\mathrm{Mg}^{2+}$ by AS Tartu Veevärk (Water Works of Tartu).

\section{Mitigation of environmental problems in urban areas}

\subsection{Protection of roof membrane}

An exposed roof membrane absorbs solar radiation during the day and its temperature rises, while in the evening its surface temperature drops. Daily temperature fluctuations create thermal stresses in the membrane and reduce its durability. The greenroof blocks the solar radiation from reaching the membrane, thus lowering its temperature and also minimizing temperature fluctuations. The life span of the membrane of a conventional roof is usually 20-25 years, but it is believed that a greenroof membrane may last twice as long.

During the 22-month observation period (660 days) in Ottawa, Canada, Liu [3] found that the membrane temperature of the reference bituminous roof exceeded $30^{\circ} \mathrm{C}$ for 342 days, was above $50^{\circ} \mathrm{C}$ for 219 days and above $60^{\circ} \mathrm{C}$ for89 days. In comparison, the membrane under the greenroof only exceeded $30^{\circ} \mathrm{C}$ for 18 days, and never reached $40^{\circ} \mathrm{C}$. The temperature fluctuation in the exposed membrane of the reference roof had a median of $42-47^{\circ} \mathrm{C}$. The greenroof reduced the temperature fluctuation in the roof membrane to a median fluctuation of $5-7^{\circ} \mathrm{C}$ throughout the year. Wong et al [4] found that surface temperatures measured under different kinds of vegetation were much lower than 
those measured on hard surfaces. The maximum temperature of the hard surface and under all kinds of plants was $57^{\circ} \mathrm{C}$ and $36^{\circ} \mathrm{C}$ respectively.

The Estonian study produced the following main results. In the summer months, from June to August, the LWA's surface heats and cools faster (amplitude $4.7^{\circ} \mathrm{C}$ to $54.8^{\circ} \mathrm{C}$ ) on the sunny days than the surface of the bituminous roof $\left(6.1^{\circ} \mathrm{C}\right.$ to $\left.52.7^{\circ} \mathrm{C}\right)$, remaining coolest at night. The temperature fluctuation at a depth of $100 \mathrm{~mm}$ was only $23.9^{\circ} \mathrm{C}\left(10.3^{\circ} \mathrm{C}\right.$ to $\left.34.2^{\circ} \mathrm{C}\right)$, and soil temperature was also more stable. Therefore the greenroof's substrate layer reduced summer temperature fluctuations by $22.7^{\circ} \mathrm{C}$. The number of days on which the temperature exceeded $30^{\circ} \mathrm{C}$ was 63 for the bituminous roof, but only 9 at a depth of $100 \mathrm{~mm}$ of the greenroof's soil. Although LWA surface heating in the daytime and cooling in the evening involves corresponding changes in soil temperature, the latter fluctuates notably less, and thus the base roof is protected from large temperature fluctuations. The temperature at a depth of $100 \mathrm{~mm}$ rises slowly until afternoon, and then begins to fall just as slowly. At a depth of 50 $\mathrm{mm}$ the temperature runs in the same way, but is higher before noon and lower after noon. Since in summer the LWA's temperature fluctuates even a little more than the temperature of the bituminous membrane, the immediate establishment of vegetation is recommended. In the autumn months (September-November), temperatures did not change much, due to cool and cloudy weather.

In winter (December-March) temperatures were low both on the surface of the greenroof $\left(\min -13.6^{\circ} \mathrm{C}\right)$ and in the soil $\left(\min -9.8^{\circ} \mathrm{C}\right)$, because the snow cover was thin due to ablation by snowstorms. The reference roof was covered by a $200 \mathrm{~mm}$ thick snow layer, which kept the surface temperature relatively stable $\left(\min -8^{\circ} \mathrm{C}\right.$ ). In the winter days, the insulating effect of the snow cover is apparent. In spite of the equal thickness of the snow cover, the greenroof's soil temperature is several degrees higher than the temperature of the surface of the reference roof. In spring the temperatures of roof surfaces fluctuated considerably due to daily sunshine and night frosts, whereas soil temperature was more stable. When the daytime sun heats and the night freezes it, the amplitude of the soil temperature $\left(1.3^{\circ} \mathrm{C}\right)$ is remarkably less than that of the surface $\left(20.1^{\circ} \mathrm{C}\right)$.

\subsection{Reducing heat flow and energy cost}

Greenroofs are recognized as providing thermal performance and roof insulation for buildings. Of the total solar radiation absorbed by the planted roof, $27 \%$ is reflected by the plants, $60 \%$ is absorbed by the plants and the soil, and $13 \%$ is transmitted into the soil [5]. Many researches [5-9] have demonstrated that greenroofs reduce diurnal temperature variations in buildings by blocking solar radiation, which contributes to energy conservation. The greenroof acted as a thermal mass that effectively dampened the thermal fluctuations going through the roofing system. In the summer period a greenroof's cooling effect is higher due to the evapotranspiration from plants and the evaporation of retained moisture from the soil. In the winter period a greenroof can help to reduce heat loss from buildings that act as an insulation membrane (Table 1). 
The Sustainable City IV: Urban Regeneration and Sustainability 7

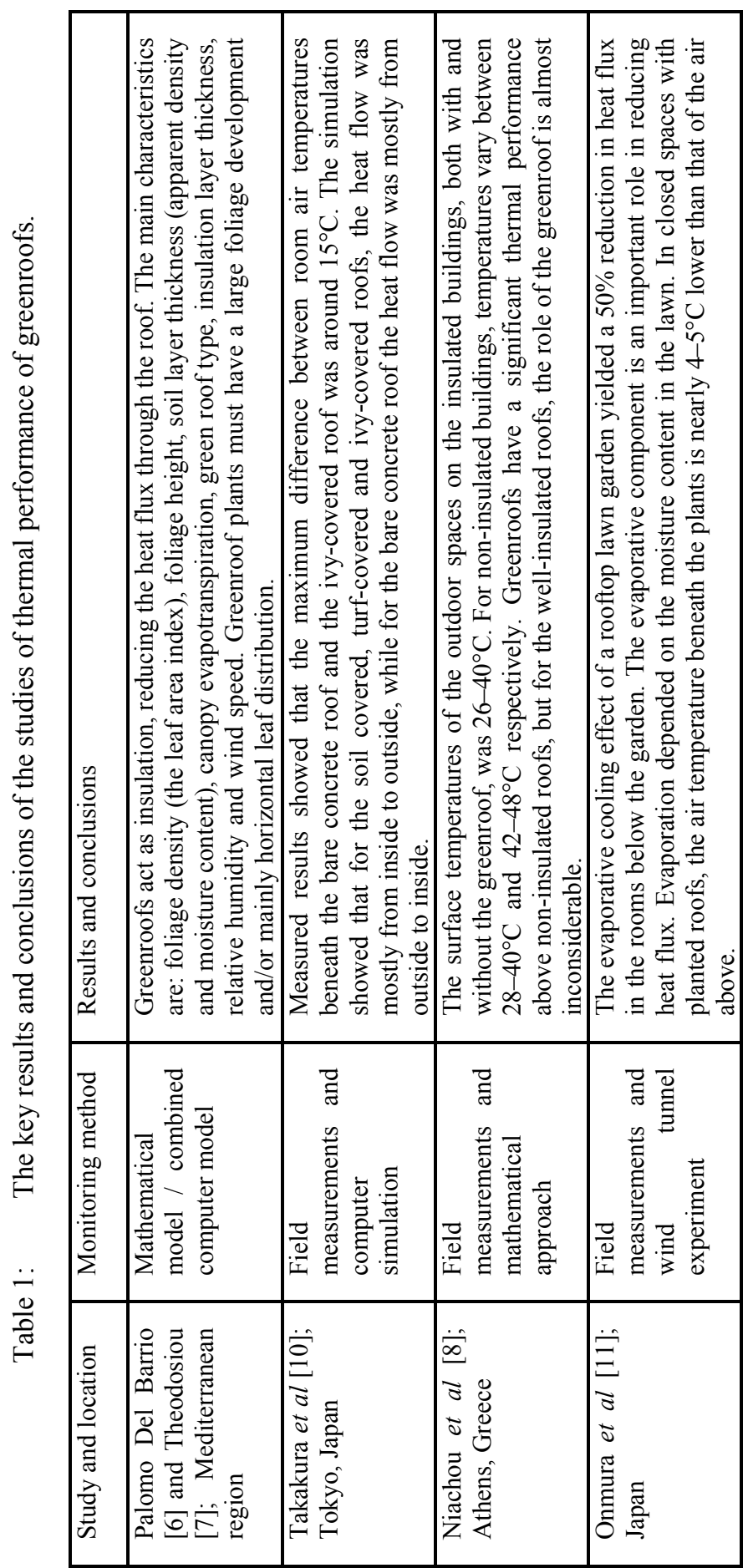

WIT Transactions on Ecology and the Environment, Vol 93, (C) 2006 WIT Press www.witpress.com, ISSN 1743-3541 (on-line) 


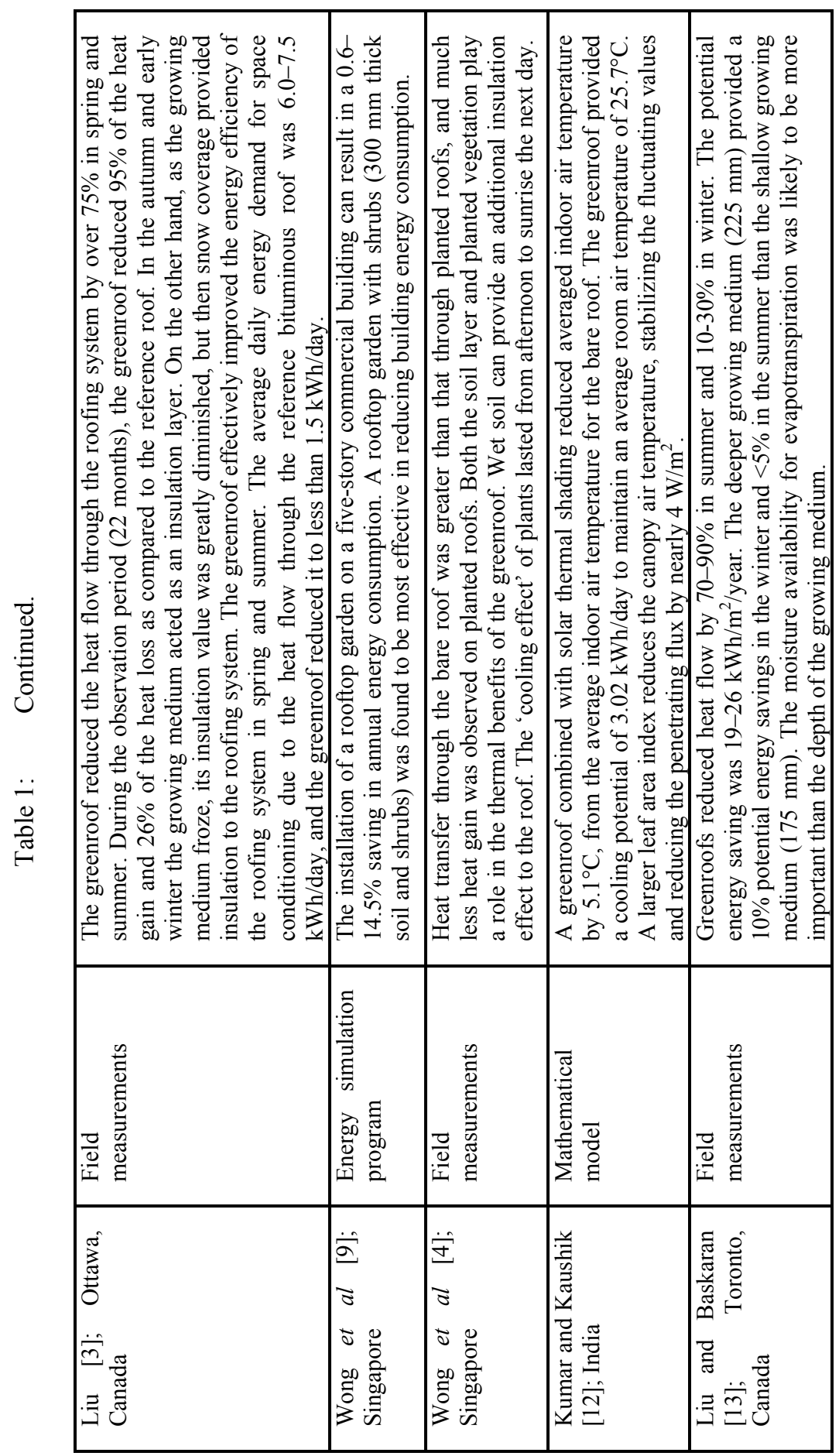

WIT Transactions on Ecology and the Environment, Vol 93, (c) 2006 WIT Press www.witpress.com, ISSN 1743-3541 (on-line) 


\subsection{Reducing the urban heat island effect}

The 'urban heat island effect' (UHI) is the difference in temperature between urban areas and the surrounding undeveloped areas. It is caused by changes in the natural water and energy balance. Cities have large areas of dark materials such as roofs that absorb solar radiation and reflect this heat back into the atmosphere at night. The result of the UHI effect is that urban areas have higher air temperatures and lower air humidity than in the surrounding undeveloped areas. The intensity of a UHI depends on many factors, such as the size of the city and its energy consumption, geographical location, heat emission, absence of green space, month or season, time of day, and synoptic weather conditions [14]. Greenroofs can reduce UHI effect by increasing evapotranspiration, which creates a cooling effect, thereby reducing the temperature of the surroundings. But this effect is only more noticeable when numerous greenroofs are established side by side.

Gomez et al [15] found that there was a heat difference of over $5^{\circ} \mathrm{C}$ between the city centre and the rural areas. The difference in temperatures between the city and the rural areas was $1.3^{\circ} \mathrm{C}$. In green areas the temperature was about $2.5^{\circ} \mathrm{C}$ below the city's maximum temperature. Using the Mesoscale Compressible Community Model, Liu and Bass [16] showed that urban irrigation reduced average urban temperatures by $1^{\circ} \mathrm{C}$. The addition of irrigated greenroofs located in the downtown area increased the cooling effect to $2^{\circ} \mathrm{C}$ and extended the $1^{\circ} \mathrm{C}$ cooling region over a larger geographic area. The simulation showed that with sufficient moisture for evapotranspiration, greenroofs can reduce the UHI effect.

\subsection{Reducing rainwater runoff problems}

Rainfall in urban areas is typically more problematic than in rural areas, because of impervious surfaces such as roofs, parking-lots and roads. These collect the flow and direct it into the urban drainage system, causing rapid runoff and higher peak flows. Greenroofs reduce rainwater runoff and thereby mitigate this problem. The reduction consists in delaying the initial time of runoff due to the absorption of water in the greenroof, reducing the total runoff by retaining part of the rainfall and distributing the runoff over a long time period through a relatively slow release of the excess water that is stored in the substrate layer [17]. The amount retained depends on many factors such as the volume and intensity of rainfall, the amount of time since the previous rainfall event, the depth and wetting scale of the growing medium and the roof slope. The main results and conclusions are presented in table 2 .

The mean process by which a greenroof reduces a roof's runoff is evapotranspiration. Kolb [18] studied the evapotranspiration ability of greenroof plots (growing medium 50-140 mm) in Veitshöchheim, Germany, and found that, with an average monthly rainfall of $47 \mathrm{~mm}$, evaporation was $21 \mathrm{~mm} \mathrm{(45 \% )}$ during the year. Between May and August almost all rainfall evaporated, and between November and February evaporation was insignificant. 


\begin{tabular}{|c|c|c|c|c|c|}
\hline $\begin{array}{l}\frac{\mathscr{0}}{\tilde{0}} \\
\frac{\mathscr{0}}{0} \\
\frac{0}{0} \\
\stackrel{0}{0}\end{array}$ & 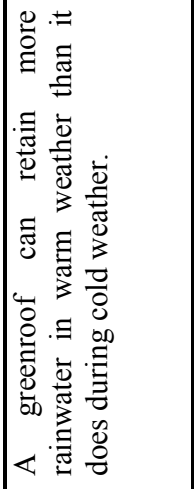 & 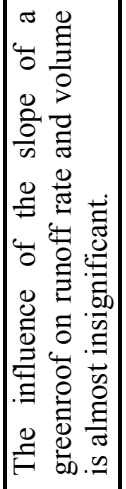 & & 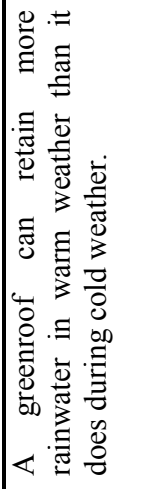 & 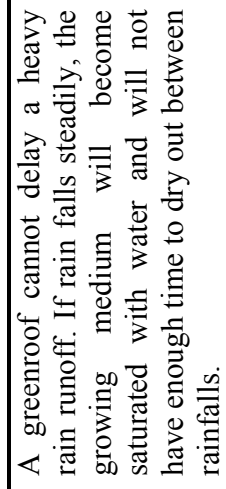 \\
\hline 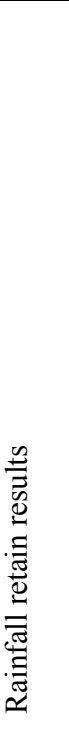 & 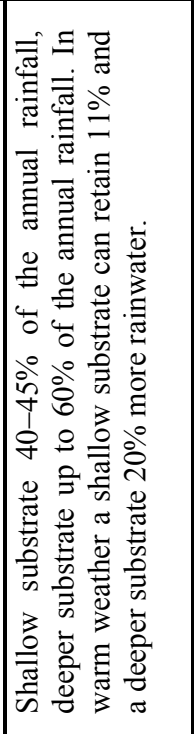 & 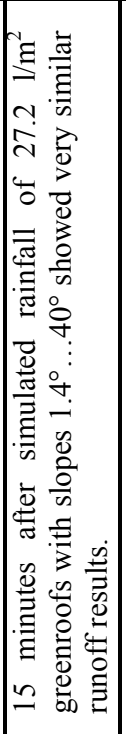 & 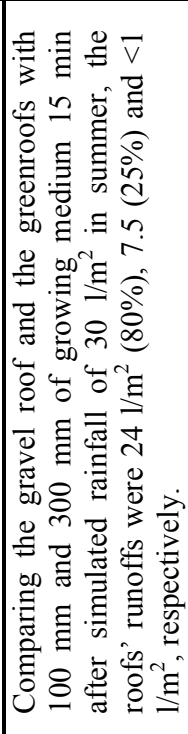 & 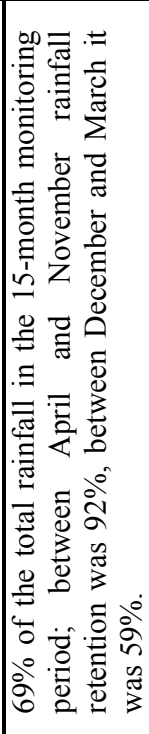 & 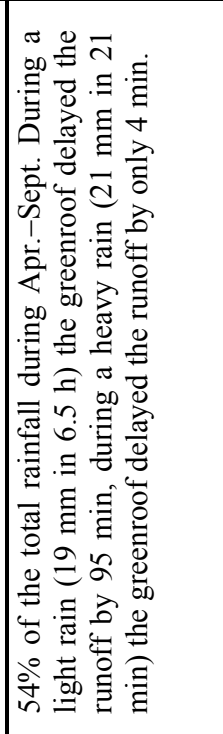 \\
\hline 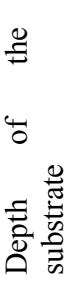 & 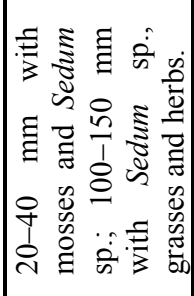 & $\mid$ & 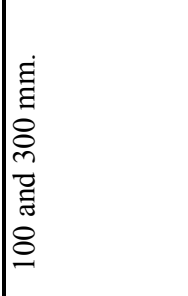 & & 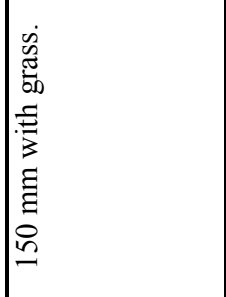 \\
\hline 宅 & 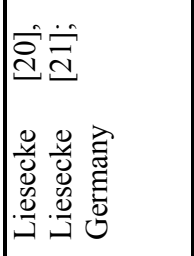 & 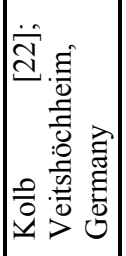 & 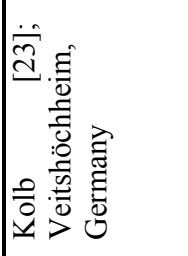 & 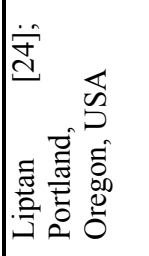 & 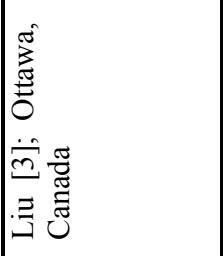 \\
\hline
\end{tabular}




\begin{tabular}{|c|c|c|c|c|}
\hline 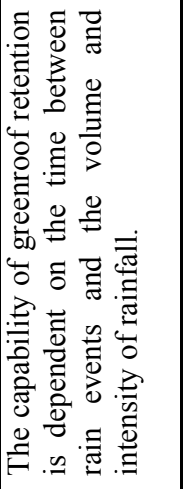 & 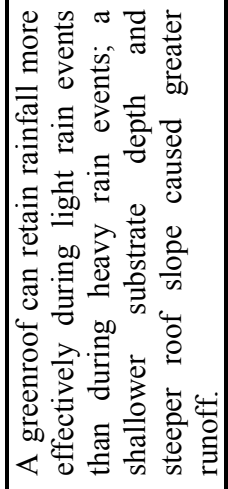 & 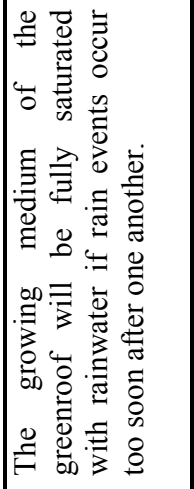 & & 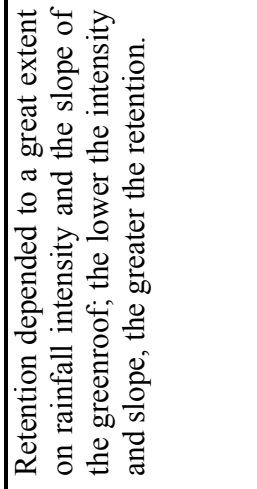 \\
\hline 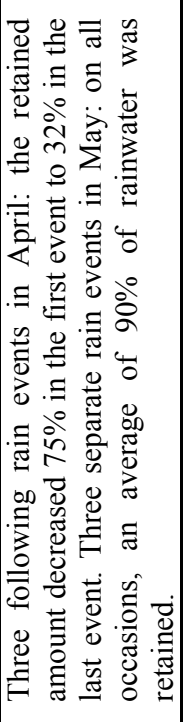 & 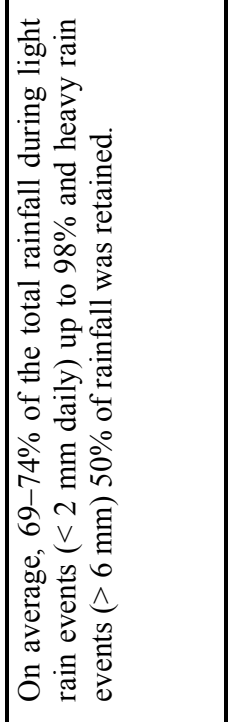 & 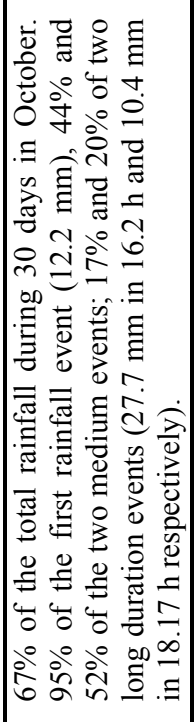 & 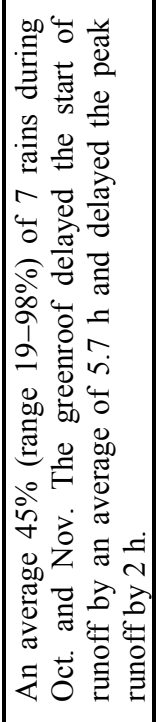 & 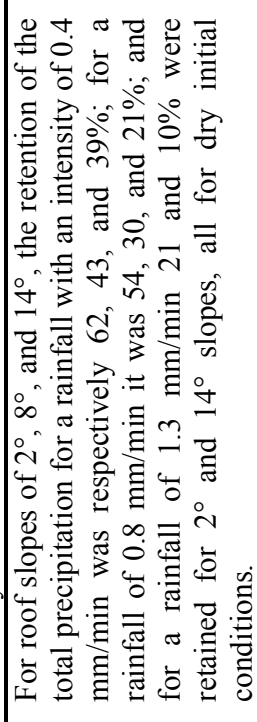 \\
\hline 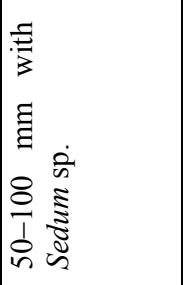 & 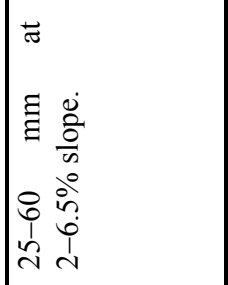 & 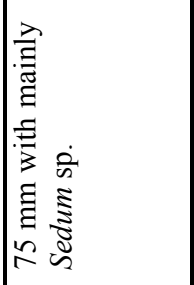 & 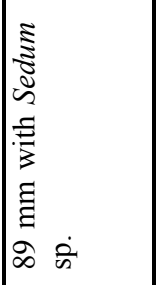 & 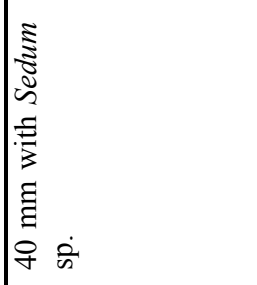 \\
\hline 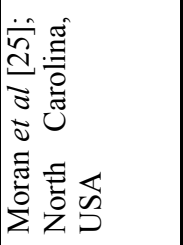 & 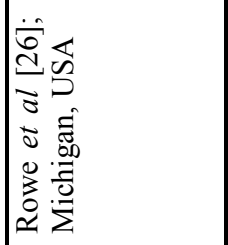 & 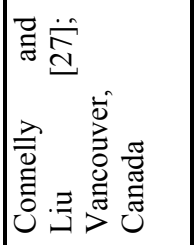 & 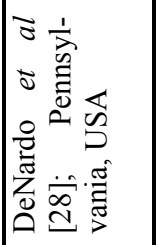 & 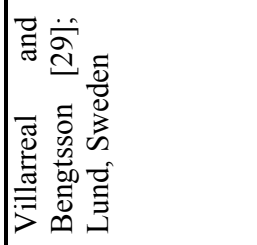 \\
\hline
\end{tabular}


Mentens et al [19] studied in Belgium how evaporation is influenced by orientation of the slope. They found that there is a significant interaction with period, day and orientation. Evaporation is significantly different between all orientations except for east and west, being bigger in south-facing slopes than north-facing ones.

Mentens et al [17] offers a review of the investigations of greenroof runoff retention capability, which were mainly performed in Germany. For annual runoff, they found that runoff is mainly determined by the roof type, and may be as low as $15 \%$ for an intensive greenroof and as high as $91 \%$ for a traditional non-greened roof. For seasonal runoff, the results showed that greenroof runoff was significantly higher during winter $(80 \%)$ than during summer $(52 \%)$. For three seasons runoff is $30 \%$ for the warm, $51 \%$ for the cool and $67 \%$ for the cold season; substrate depth was significantly important for the warm season.

The water retention capability results of the Estonian study are similar to the results of the studies presented in Table 2. In the Estonian study three rain events were investigated. Two light rains were measured: rainfall of $2.1 \mathrm{~mm}(2.08 .04)$ and rainfall of $2.6 \mathrm{~mm}(1.4+1.2 \mathrm{~mm} ; 14 .-15.09 .04)$. The greenroof retained these rainfalls well - runoff was 32.6 and 19.31 respectively, while the runoff from the reference roof was 290 and 3401 respectively. For the first rainfall, runoff from the greenroof ceased 10 hours later than runoff from the reference roof. Therefore the retention was 88.8 and $94.3 \%$ respectively. Exceptionally in the course of 4 days, a $18.2 \mathrm{~mm}$ rainfall took place (31.08.04-06.09.04). 12.1 $\mathrm{mm}$ fell during the first 5 hours. It appeared that in the case of a heavy rainstorm, a greenroof can delay the runoff for up to half an hour, but cannot fully retain it. From both roofs an estimated 28501 water ran off during those days. 12401 ran off from the first outflow of the greenroof ( $g r 1)$, which collected water from the more heavily plant-covered side, and 16501 ran off from the second (gr2), less plant-covered side. Gr1 runoff finished later than the others, but still 40 hours after the other outflows.

The melting of the snow cover with an average thickness of $220 \mathrm{~mm}$ of the greenroof was also observed over 17 days (22.03.05-07.04.05). It was to be expected that water came off less and more slowly from the more plant-covered side of the greenroof, and more rapidly from the less plant-covered side (by 995 1). When the snow on the greenroof melted within one day, the runoff was about to cease, but started again after a couple of days, as the lower part of the substrate layer only began to melt then. The total runoff from the greenroof was 31951 , and 40661 from the reference roof, because of the thicker layer (average thickness $290 \mathrm{~mm}$ ) of snow.

\subsection{Reducing urban rainwater runoff quality problems}

Greenroofs may reduce the pollution of urban rainwater runoff by absorbing and filtering the pollutants, but they can also potentially contribute to pollutants released into water from the soil, plants and fertilizers. The runoff quality from a greenroof depends on the type of the roof (the thickness of the growing medium, its composition, vegetation and the type of drainage), the age of the roof, its maintenance; and also on the type of the surrounding area and the local pollution 
sources [30]. For the majority of roof runoff water components, the results differ depending on the different greenroof systems and the composition of the growing medium. The main results and conclusions are presented in Table 3.

Table 3: The key results and conclusions of the studies of greenroofs' runoff water quality.

\begin{tabular}{|c|c|}
\hline $\begin{array}{l}\text { Study and } \\
\text { location }\end{array}$ & Results and conclusions \\
\hline $\begin{array}{l}\text { Kolb [31]; } \\
\text { Bayern, } \\
\text { Germany }\end{array}$ & $\begin{array}{l}\text { Metal roofs with greenery cover reduced copper and zinc } \\
\text { concentrations in roof runoff. For three year measurements, the } \\
\text { copper concentration in the percolating water of a non-greened } \\
\text { copper-sheet roof increased from } 0.9 \text { to } 2 \mathrm{~g} \text {, and in a greened roof } \\
\text { it only increased from } 0.8 \text { to } 1.1 \mathrm{~g} \text {. The zinc concentration in } \\
\text { percolating water of non-greened zinc-sheet roof increased from } \\
3.5 \text { to } 4.8 \mathrm{~g} \text {, whereas in greened roof it decreased from } 5 \text { to } 1.9 \mathrm{~g} \text {. }\end{array}$ \\
\hline $\begin{array}{l}\text { Köhler and } \\
\text { Schmidt } \\
\text { [32]; Berlin, } \\
\text { Germany }\end{array}$ & $\begin{array}{l}\text { The tested greenroof substrates cause a rise in } \mathrm{pH} \text { : in rainfall, } \\
\text { median } \mathrm{pH} \text { was } 6.2 \text {, in the runoff of the conventional roof it was } \\
4.6 \text {, and in the runoff of substrates it was up to } 7.5 \text {. } \\
\text { Greenroof plots retained } 94.7 \% \text { of lead, } 87.6 \% \text { of cadmium, } 80.2 \% \\
\text { of nitrates and } 67.5 \% \text { of phosphates over a three-year period. The } \\
\text { efficiency of phosphate retention increased after the establishment } \\
\text { of the vegetation from } 26 \% \text { in the first year to } 80 \% \text { in the fourth } \\
\text { year. }\end{array}$ \\
\hline $\begin{array}{l}\text { Liptan and } \\
\text { Strecker } \\
{[33]} \\
\text { Portland, } \\
\text { Oregon, } \\
\text { USA }\end{array}$ & $\begin{array}{l}\text { There was a decreasing trend in the total phosphorous } \\
\text { concentrations measured in greenroof runoff. Phosphorous } \\
\text { concentrations varied between } 0.24-1.11 \mathrm{mg} / \mathrm{l} \text {. The copper } \\
\text { concentration in greenroof runoff was } 4.8-10.5 \mu \mathrm{g} / \mathrm{l} \text {, caused by the } \\
\text { materials to be used on the roof, for example drainage materials. } \\
\text { However, the copper loading would be much reduced in } \\
\text { comparison to a traditional roof. }\end{array}$ \\
\hline $\begin{array}{l}\text { Moran et al } \\
\text { [25]; North- } \\
\text { Carolina, } \\
\text { USA }\end{array}$ & $\begin{array}{l}\text { The results showed that compost in the growing medium may } \\
\text { cause high concentrations of nitrogen and phosphorus in greenroof } \\
\text { runoff. Total nitrogen and total phosphorus concentrations in four } \\
\text { greenroof runoff samples was } 2.1-5.4 \mathrm{mg} / 1 \text { and } 1.2-1.5 \mathrm{mg} / \mathrm{l} \text {, and } \\
\text { in rainfall } 0.3-0.7 \mathrm{mg} / \mathrm{l} \text { and } 0.05 \mathrm{mg} / 1 \text { respectively. }\end{array}$ \\
\hline $\begin{array}{l}\text { Berndtsson } \\
\text { et al [30]; } \\
\text { Malmö and } \\
\text { Lund, } \\
\text { Sweden }\end{array}$ & $\begin{array}{l}\text { The studied greenroofs behave as a sink of nitrate nitrogen; they } \\
\text { reduced ammonium nitrogen and total nitrogen. They are sources } \\
\text { of potassium, phosphate phosphorus and total phosphorus. Young } \\
\text { greenroofs behave as a source of total nitrogen, more than others. } \\
\text { All of the heavy metals measured }(\mathrm{Cd}, \mathrm{Cr}, \mathrm{Cu}, \mathrm{Fe}, \mathrm{Mn}, \mathrm{Pb}, \mathrm{Zn}) \\
\text { were usually the same or lower than in the precipitation and } \\
\text { reference roof runoff. Some studied greenroofs contributed lead, } \\
\text { manganese and iron to runoff. However, greenroofs behave as a } \\
\text { sink for copper and zinc. It should be noted that metals that are } \\
\text { first retained by the roof can potentially be released from it when } \\
\text { the roof ages. }\end{array}$ \\
\hline
\end{tabular}

In Estonia, water quality was studied at three runoff events. When the rain and runoff were moderate, concentrations of $\mathrm{COD}, \mathrm{BOD}_{7}, \mathrm{TN}$ and $\mathrm{TP}$ were 
higher on the bituminous roof; $\mathrm{pH}$ on both roofs increased by more than 2 units. In samples taken in case of a heavy rainstorm, the components were less concentrated, as the rain washed more phosphates and nitrates out of the greenroof. In snowmelt, the water concentrations of all components were greater on the greenroof, because the greenroof contained more wintertime pollutants. In addition, the greenroof runoff always contained more sulphates and $\mathrm{Ca}-\mathrm{Mg}$-salt because of their presence in the LWA-material.

In the Estonian study, the concentrations of total nitrogen and total phosphorus were much lower than that in the Moran et al [25] or Liptan and Strecker [33] studies, because the Estonian greenroof did not contain compost like the others. Therefore, in the Estonian study total phosphorous concentration was $0.03-0.09 \mathrm{mg} / \mathrm{l}$, and total nitrogen concentration $1-2.1 \mathrm{mg} / \mathrm{l}$. Thus the composition of the growing medium should be taken into consideration in selecting the soil mix.

\subsection{Other greenroof benefits}

In addition to the above-mentioned benefits, greenroofs also improve air quality, by catching a number of polluting air particles and gases, as well as smog. The evaporation and oxygen producing effect of vegetated roofs can contribute to the improvement of the microclimate. Greenroofs can also mitigate noise pollution. The substrate layer blocks lower sound frequencies and the plants block higher frequencies. In a standard test, an unvegetated roof reduced sound by $33 \mathrm{~dB}$. The greenroof reduced sound by $41 \mathrm{~dB}$ when dry, and $51 \mathrm{~dB}$ when wet [1]. In city centres, where access to green space is negligible, greenroofs create space where people can rest and interact with friends or business colleagues. Greenroofs provide a psychological benefit because of their appearance, which differs greatly from the ordinary. Therefore, aesthetic value is the most apparent benefit of greenroofs. Planted roofs also provide food, habitat and a safe place for many kinds of plants, animals and invertebrates.

\section{Conclusion}

This study showed that greenroofs can be effectively used in the mitigation of environmental problems in urban areas. Greenroofs are effective in helping to keep the building cool in summer and also to reduce building energy consumption. Their ability to effectively reduce the effect of urban heat islands was not sufficiently investigated, but it surely may be concluded that greenroofs are well able to do that. We may confirm that vegetated roofs reduce the temperature fluctuation in the roof membrane and prolong its lifespan. Greenroofs delay effectively rainfall runoff rate and volume, more in warm and less in cold period. The greenroofs' runoff water quality was not as good as may be expected. Further investigations of the benefits of greenroofs will definitely be necessary in order to obtain more exact results on all of these topics and to confirm their ability to reduce environmental problems. 


\section{Acknowledgement}

This study was supported by Target Funding Project No. 0182534 s03 of the Ministry of Education and Science of Estonia.

\section{References}

[1] Grant, G., Engelback, L. \& Nicholson, B., Green roofs: their existing status and potential for conserving biodiversity in urban areas. English Nature Research Report number 498, EcoSchemes Ltd, 2003.

[2] England, E., Morgan, B., Usrey, L., Greiner, M. \& Bleckmann, C., Vegetated roofing technology: an evaluation. $4^{\text {th }}$ International Life Cycle Assessment and Life Cycle Management Conference, 11-24 ${ }^{\text {th }}$ July, 2004.

[3] Liu, K., Engineering performance of rooftop gardens through field evaluation. RCI $18^{\text {th }}$ International Convention and Trade Show, Tampa, Florida, 13-18 $8^{\text {th }}$ March, pp. 1-15, 2003.

[4] Wong, N.H., Chen, Y., Ong, C.L. \& Sia, A., Investigation of thermal benefits of rooftop garden in the tropical environment. Build. Environ., 38, pp. 261-270, 2003.

[5] Eumorfopoulou, E. \& Aravantinos, D., The contribution of a planted roof to the thermal protection of buildings in Greece. Energ. Buildings, 27, pp. 29-36, 1998.

[6] Palomo Del Barrio, E., Analysis of the green roofs cooling potential in buildings. Energ. Buildings, 27, pp. 179-193, 1998.

[7] Theodosiou, T.G., Summer period analysis of the performance of a planted roof as a passive cooling technique. Energ. Buildings, 35, pp. 909-917, 2003.

[8] Niachou, A., Papakonstantinou, K., Santamouris, M., Tsangrassoulis, A. \& Mihalakakou, G., Analysis of the green roof thermal properties and investigation of its energy performance. Energ. Buildings, 33, pp. 719 $729,2001$.

[9] Wong, N.H., Cheong, D.K.W., Yan, H., Soh, J., Ong, C.L. \& Sia, A., The effects of rooftop gardens on energy consumption of a commercial building in Singapore. Energ. Buildings, 35, pp. 353-364, 2003.

[10] Takakura, T., Kitade, S. \& Goto, E., Cooling effect of greenery cover over a building. Energ. Buildings, 31, pp. 1-6, 2000.

[11] Onmura, S., Matsumoto, M. \& Hokoi, S., Study of evaporative cooling effect of roof lawn gardens. Energ. Buildings, 33, pp. 653-666, 2001.

[12] Kumar, R. \& Kaushik, S.C., Performance evaluation of green roof and shading for thermal protection of buildings. Build. Environ., 40(11), pp. 1505-1511, 2005.

[13] Liu, K. \& Baskaran, B., Green roof infrastructure - technology demonstration, monitoring and market expansion project. Part 1: field monitoring and technical analysis: May 2002 - June 2003. NRC-IRC, Report no B-1054.1., 2005.

[14] Oke, T.R., Boundary layer climates. Wiley and Sons, 372 pp., 1987. 
[15] Gomez, F., Gaja, E. \& Reig, A., Vegetation and climatic changes in a city. Ecol. Eng., 10, pp. 355-360, 1998.

[16] Liu, K. \& Bass, B., Performance of green roof systems. Cool Roofing Symposium, Atlanta, USA, 12-13 ${ }^{\text {th }}$ May, pp. 1-18, 2005.

[17] Mentens, J., Raes, D. \& Hermy, M., Green roofs as a tool for solving the rainwater runoff problem in the urbanized $21^{\text {st }}$ century? Landscape Urban Plann., in press, available online since 13 May 2005.

[18] Kolb, W., Gute Gründe für die Dachbegrünung - Gründach und Regenwasser. Dach + Grün, 1, pp. 4-9, 2002.

[19] Mentens, J., Raes, D. \& Hermy, M., Effect of orientation on the water balance of greenroofs. In Proc. of $1^{\text {st }}$ North American Green Roof Conference: Greening Rooftops for Sustainable Communities, Chicago, 29-30 ${ }^{\text {th }}$ May, The Cardinal Group, Toronto, pp. 363-371, 2003.

[20] Liesecke, H., Wasserrückhaltung bei Extensive Dachbegrünungen. Deutscher Gartenbau, 47(34), pp. 2142-2147, 1993.

[21] Liesecke, H., Das Retentionsvermögen von Dachbegrünungen. Stadt und Grün, 47, pp. 46-53, 1998.

[22] Kolb, W., Einfluss der Oberflächhenneigung auf die Abflussverhältnisse von enlighten Dächern. Dachbegrünung - Veitshöchheimer Berichte, 66, pp. 101-106, 2002.

[23] Kolb, W., Wasserrückhalt der Dachbegrünung. Rasen-Turf-Gazon, 2, pp. 36-41, 2003.

[24] Liptan, T., Planning, zoning and financial incentives for ecoroofs in Portland, Oregon. In Proc. of $1^{\text {st }}$ North American Green Roof Conference: Greening Rooftops for Sustainable Communities, Chicago, 29-30 ${ }^{\text {th }}$ May, The Cardinal Group, Toronto, pp. 113-120, 2003.

[25] Moran, A., Hunt, B. \& Jennings, G., A North Carolina field study to evaluate greenroof runoff quantity, runoff quality, and plant growth. ASAE Annual International Meeting, Las Vegas, Nevada, USA, 27-30 July, Paper No. 032303, 2003.

[26] Rowe, D., Rugh, C., VanWoert, N., Monterusso, M. \& Russell, D., Green roof slope, substrate depth, and vegetation influence runoff. In Proc. of $1^{\text {st }}$ North American Green Roof Conference: Greening Rooftops for Sustainable Communities, Chicago, 29-30 ${ }^{\text {th }}$ May, The Cardinal Group, Toronto, pp. 354-362, 2003.

[27] Connelly, M. \& Liu, K., Green roof research in British Columbia - an over-view. $3^{\text {rd }}$ North American Green Roof Conference: Greening rooftops for Sustainable Communities, Washington, D.C., 5-6 ${ }^{\text {th }}$ May, pp. 1-17, 2005.

[28] DeNardo, J.C., Jarrett, A.R., Manbeck, H.B., Beattie, D.J. \& Berghage, R.D., Stormwater mitigation and surface temperature reduction by green roofs. Transactions of the ASAE, 48(5), pp. 1491-1496, 2005.

[29] Villarreal, E.L. \& Bengtsson, L., Response of a Sedum green-roof to individual rain events. Ecol. Eng., 25, pp. 1-7, 2005. 
[30] Berndtsson, J.C., Emilsson, T. \& Bengtsson, L., The influence of extensive vegetated roofs on runoff water quality. Sci. Total Environ., 355(1-3), pp. 48-63, 2006.

[31] Kolb, W., Metalleindeckung für Gründächer. Grün Forum LA, 12, pp. 2022, 2002.

[32] Köhler, M. \& Schmidt, M., Study of extensive green roofs in Berlin. Available online at: http://www.roofmeadow.com/waterquality.html, 2003.

[33] Liptan, T. \& Strecker, E., EcoRoofs (Greenroofs) - a more sustainable infrastructure. National Conference on Urban Stormwater: Enhancing Programs at the Local Level, 17-20 ${ }^{\text {th }}$ February, 2003. 